\title{
PENGARUH KEPEMIMPINAN DAN PENEMPATAN TERHADAP SEMANGAT KERJA DAN KINERJA PEGAWAI SEKRETARIAT DAERAH KABUPATEN ROKAN HULU
}

\author{
Roni Candra ${ }^{1}$, Sri Indarti ${ }^{2}$, Yusni Maulida ${ }^{3}$ \\ ${ }^{1)}$ Mahasiswa Program Pasca Sarjana Universitas Riau \\ ${ }^{233)}$ Dosen Program Pasca Sarjana Universitas Riau \\ Email : ronichandra606@gmail.com ${ }^{1}$
}

\begin{abstract}
This study aims to determine the effect of leadership and placement on employee morale and performance of Regional Secretariat of Rokan Hulu Regency. This study aims to determine the effect of leadership and placement on morale and performance of Regional Secretariat of Rokan Hulu Regency. This research is a quantitative descriptive study. The data used in this study are primary data by giving questionnaires to all ASN in the Regional Secretariat of Rokan Hulu Regency and secondary data obtained from several literatures, documents, reports and scientific papers as well as other supporting related to this research. Data analysis method used in this study is path analysis to test hypotheses with the help of SPSS For Windows Version 21 software. The results showed that there was a positive and significant direct effect between leadership on morale, leadership on performance, and morale on employee morale on the performance of the Regional Secretariat. While the placement variable on morale and placement on performance there is a positive but not significant direct effect. The indirect effect of leadership on performance through morale is positive and significant, while the placement variable on performance through morale is positive but not significant.
\end{abstract}

Keywords: Leadership, Placement, Morale, Performance

\section{LATAR BELAKANG}

Sekretariat

berdasarkan Peraturan

Daerah,

Daerah

Kabupaten Rokan Hulu Nomor 5 Tahun 2016 tentang Pembentukan dan Susunan Perangkat Daerah adalah unsur staf membantu Bupati dalam penyusunan kebijakan dan pengkoordinasian administrasi terhadap pelaksanaan tugas perangkat daerah serta pelayanan publik. Sekretariat Daerah dipimpin oleh Sekretaris Daerah, membawahi 3 orang Asisten, 10 Bagian dan 30 Sub Bagian. Saat ini Sekretariat Daerah memiliki jumlah pegawai sebanyak 321 orang terdiri dari 103 orang ASN dan 218 orang Tenaga Honorer.

Dari sisi penilaian kinerja pegawai berdasarkan indikator pengukuran Sasaran Kinerja Pegawai Negeri pada Sekretariat Daerah Kabupaten Rokan Hulu untuk tahun 2017 rata-rata prestasi kerja pegawai Sekretariat Daerah berada dalam kategori baik yaitu range 76 s.d. 90 . Menurut penulis capaian penilaian SKP dan perilaku kerja ini belum mencerminkan kinerja pegawai secara keseluruhan karena pada kenyataannya penilaian SKP belum dilakukan secara objektif dan masih bersifat administratif, artinya penilaian SKP dan perilaku kerja 
terkesan hanya sebagai salah satu syarat administrasi untuk kenaikan pangkat Pegawai Negeri Sipil. Masih ada "kelonggaran" dalam pemberian penilaian SKP.

Menurut penulis secara keseluruhan penilaian kinerja pegawai lebih dicerminkan dari penilaian kinerja organisasi secara keseluruhan yang dituangkan ke dalam Laporan Kinerja Instansi Pemerintah (LKJIP). Berikut disajikan data realisasi dan capaian kinerja berdasarkan indikator kinerja utama yang telah ditetapkan Sekretariat Daerah dari tahun 2016 s.d.

2018.

Tabel 1 Capaian Target Indikator Kinerja Utama pada Sekretariat Daerah Kabupaten Rokan Hulu Tahun 2016-2018

\begin{tabular}{|c|c|c|c|c|c|}
\hline \multirow{2}{*}{ No. } & \multirow{2}{*}{ Tahun } & \multicolumn{4}{|c|}{ Indikator Kinerja Utama } \\
\cline { 3 - 6 } & & Target Capaian & Realisasi Capaian & $\begin{array}{l}\text { Tidak } \\
\text { Tercapai }\end{array}$ & \% Capaian \\
\hline 1. & 2016 & 24 Target & 19 Target & 5 Target & $79,20 \%$ \\
\hline 2. & 2017 & 24 Target & 18 Target & 6 Target & $75,00 \%$ \\
\hline 3. & 2018 & 23 Target & 11 Target & 12 Target & $47,80 \%$ \\
\hline
\end{tabular}

Sumber : LKJIP Sekretariat Daerah Tahun 2016-2018

Dari tabel 1 dapat dilihat bahwa untuk tahun 2016 dari 24 target tidak tercapai 5 target atau realisasinya sebesar $79,20 \%$, tahun 2017 dari 24 target tidak tercapai 6 target atau realisasinya $75 \%$, sedangkan di tahun 2018 dari 23 target hanya terealisasi 11 target atau sebesar 47,8\%. Hal ini menunjukkan bahwa target yang diberikan berdasarkan kuantitas tidak pernah tercapai maksimal sesuai dengan yang telah ditentukan. Penurunan capaian kinerja terbesar terjadi di tahun 2018. Penurunan kinerja kemungkinan disebabkan kepemimpinan yang kurang memberikan motivasi, pengawasan dan kepedulian pada bawahan, serta penempatan pegawai atau ASN yang tidak sesuai dengan kualifikasi yang diperlukan pada posisi tersebut..

Dari segi waktu pelaksanaan pelaksanaan pekerjaan juga ada beberapa indikator kinerja yang tidak tercapai atau waktu pelaksanaanya tidak sesuai dengan target penyelesaian yang semestinya, waktu penyelesaian terlambat dari jadwal sehingga berakibat terlambatnya proses realisasi kegiatan lainnya yang berhubungan. Data waktu penyelesaian pekerjaan dapat ditampilkan pada table berikut ini: 
Tabel 2 Capaian Target Waktu Pelaksanaan Pekerjaan Pada Sekretariat Daerah Kabupaten Rokan Hulu Tahun 2018

\begin{tabular}{|c|c|c|c|c|}
\hline No. & $\begin{array}{c}\text { Indikator } \\
\text { Kinerja Utama }\end{array}$ & $\begin{array}{l}\text { Bagian Yang } \\
\text { Menangani }\end{array}$ & Waktu Pelaksanaan Semestinya & Realisasi Waktu Pelaksanaan \\
\hline 1 & 2 & 3 & 4 & 5 \\
\hline 1 & $\begin{array}{l}\text { Pengumuman } \\
\text { Rencana Umum } \\
\text { Pengadaan } \\
\text { Barang/ Jasa } \\
\text { (RUP) }\end{array}$ & $\begin{array}{l}\text { Bagain Layanan } \\
\text { Pengadaan } \\
\text { Barang/Jasa }\end{array}$ & $\begin{array}{l}\text { Pengumuman Rencana Umum Pengadaan } \\
\text { Semestinya dilaksanakan Setelah APBD } \\
\text { Disyahkan dan Paling Lambat sebelum } \\
\text { Tahun Anggaran Berjalan atau akhir } \\
\text { Desember Sudah di Tayangkan di Aplikasi } \\
\text { SiRUP LKPP. }\end{array}$ & $\begin{array}{l}\text { Pengumuman Rencana Umum } \\
\text { Pengadaan Baru Ditayangkan } \\
100 \% \text { pada Akhir Bulan Maret } \\
\text { 2018. Mengalami } \\
\text { keterlambatan selama } 3 \text { Bulan }\end{array}$ \\
\hline 2 & $\begin{array}{l}\text { Progres Realisasi } \\
\text { Fisik dan } \\
\text { Keuangan (RFK) }\end{array}$ & $\begin{array}{l}\text { RFK ditangani Oleh } \\
\text { Bagian Ekonomi } \\
\text { Pembangunan. RFK } \\
\text { Sekretariat Daerah } \\
\text { Merupakan } \\
\text { Gabungan dari RFK } \\
\text { Seluruh Bagian Di } \\
\text { Sekretariat Daerah }\end{array}$ & $\begin{array}{l}\text { Untuk Triwulan I (Januari, Februari, Maret) } \\
\text { Progres Realisai Fisik dan Keuangan } \\
\text { Sekretariat Daerah ditargetkan sebesar 25\% } \\
\text { Dari Total Belanja Langsung }\end{array}$ & $\begin{array}{l}\text { Progres Realisai Fisik dan } \\
\text { Keuangan Sekretariat Daerah } \\
\text { Untuk Triwulan 1 Masih } \\
\text { Dibawah 25\% }\end{array}$ \\
\hline 3 & $\begin{array}{l}\text { Pelaksanaan ujian } \\
\text { sertifikasi } \\
\text { keahlian } \\
\text { barang/jasa } \\
\text { pemerintah }\end{array}$ & $\begin{array}{l}\text { Bagain Layanan } \\
\text { Pengadaan } \\
\text { Barang/Jasa }\end{array}$ & $\begin{array}{l}\text { Semestinya sesuai jadwal dilaksanakan pada } \\
\text { bulan Juni } 2018\end{array}$ & $\begin{array}{l}\text { Pelaksanaan Ujian Sertifikasi di } \\
\text { Laksanakan pada bulan } \\
\text { Agustus } 2018\end{array}$ \\
\hline 4 & $\begin{array}{l}\text { Penyediaan lahan } \\
\text { untuk kepentingan } \\
\text { umum }\end{array}$ & $\begin{array}{l}\text { Bagian Tata } \\
\text { Pemerintahan }\end{array}$ & Selama 1 Tahun Anggaran & $\begin{array}{l}\text { Belum ada pembebasan lahan } \\
\text { untuk kepentingan umum di } \\
\text { Tahun } 2018\end{array}$ \\
\hline 5 & $\begin{array}{l}\text { Jumlah } \\
\text { penyelesaian } \\
\text { batas } \\
\text { desa,kelurahan }\end{array}$ & $\begin{array}{l}\text { Bagian Tata } \\
\text { Pemerintahan }\end{array}$ & Selama 1 Tahun Anggaran & $\begin{array}{l}\text { Belum ada penyelesaian batas } \\
\text { desa/ kelurahan di Tahun } 2018\end{array}$ \\
\hline
\end{tabular}

Sumber : LKJIP Sekretariat Daerah Tahun 2018

Dari tabel 2 dapat dilihat bahwa beberapa target waktu capaian indikator kinerja utama Sekretariat Daerah dari Tahun 2018 tidak terlaksana sesuai jadwal yang telah ditetapkan. Hal ini menunjukkan bahwa target yang diberikan berdasarkan waktu penyelesaian pekerjaan tidak tercapai sesuai dengan target yang telah ditentukan.

Untuk dapat melaksanakan tugas dan tanggungjawab sangatlah diperlukan kinerja yang baik, dibutuhkan pegawai yang profesional dalam menyelesaikan pekerjaan sesuai dengan target yang telah ditentukan.

Salah satu faktor yang dapat mempengaruhi kinerja adalah semangat kerja. Semangat kerja merupakan salah satu faktor yang sangat penting untuk mendapatkan hasil kerja yang optimal. Apabila seorang pegawai memiliki semangat kerja tentunya ia akan berusaha semaksimal mungkin dengan segenap kemampuan yang dimilikinya untuk menjalankan tugasnya dengan baik.

Semangat kerja yang tinggi adalah suatu kondisi yang sangat diharapkan oleh setiap organisasi. Untuk mengetahui apakah seseorang memiliki semangat kerja yang tinggi atau rendah maka dapat dilihat dari ciri-ciri yang terlihat dalam sikap sehari-hari. Semangat kerja akan mempengaruhi tingkat absensi, untuk melihat tingkat semangat kerja karyawan, dapat dilihat dari absensi 
karyawan, untuk lebih jelasnya dapat

dilihat pada tabel berikut ini :

Tabel 3 Tingkat Absensi pegawai Sekretariat Daerah Kabupaten Rokan Hulu Tahun 2018

\begin{tabular}{|c|c|c|c|c|c|c|c|c|c|c|c|c|c|c|c|}
\hline Bulan & $\begin{array}{c}\text { Jlh } \\
\text { ASN }\end{array}$ & HK & HKP & & I & & $\mathbf{S}$ & & DD & & DL & & C & & TK \\
\hline Juni & 103 & 12 & 1.236 & 17 & $1,38 \%$ & 8 & $0,65 \%$ & 37 & $2,99 \%$ & 50 & $4,05 \%$ & - & $0,00 \%$ & 14 & $1,13 \%$ \\
\hline Juli & 103 & 22 & 2.266 & 31 & $1,37 \%$ & 2 & $0,09 \%$ & 55 & $2,43 \%$ & 116 & $5,12 \%$ & - & $0,00 \%$ & 22 & $0,97 \%$ \\
\hline Agustus & 103 & 21 & 2.163 & 17 & $0,79 \%$ & 4 & $0,18 \%$ & 58 & $2,68 \%$ & 136 & $6,29 \%$ & - & $0,00 \%$ & 21 & $0,97 \%$ \\
\hline September & 103 & 19 & 1.957 & 11 & $0,56 \%$ & 13 & $0,66 \%$ & 22 & $1,12 \%$ & 156 & $7,97 \%$ & - & $0,00 \%$ & 19 & $0,97 \%$ \\
\hline Oktober & 103 & 21 & 2.163 & 18 & $0,83 \%$ & - & $0,00 \%$ & 87 & $4,02 \%$ & 112 & $5,18 \%$ & 18 & $0,83 \%$ & 42 & $1,94 \%$ \\
\hline November & 105 & 21 & 2.205 & 25 & $1,13 \%$ & 5 & $0,23 \%$ & 136 & $6,17 \%$ & 144 & $6,53 \%$ & 28 & $1,27 \%$ & 42 & $1,90 \%$ \\
\hline Desember & 105 & 19 & 1.995 & 26 & $1,30 \%$ & 5 & $0,25 \%$ & 62 & $3,11 \%$ & 167 & $8,37 \%$ & 10 & $0,50 \%$ & 19 & $0,95 \%$ \\
\hline
\end{tabular}

Sumber : Rekap Absen Sekretariat Daerah Tahun 2018 (diolah)

Dari tabel 3 dapat dilihat bahwa tingkat absensi pegawai terutama pegawai yang tidak hadir tanpa keterangan tertinggi di bulan oktober dan bulan november 2018, sementara itu volume pekerjaan biasanya menumpuk di bulan tersebut. Ditandai dengan meningkatnya volume perjalanan dinas di bulan oktober, november dan desember. Akan tetapi di saat sebagian pegawai terutama level pimpinan sibuk melakukan perjalanan dinas, hal ini dimanfaatkan oleh sebagian pegawai sebagai alasan tidak masuk kantor. Sebagian pegawai juga memanfaatkan momen akhir tahun untuk mengambil cuti, hal ini terlihat dari persentase cuti berada di 3 bulan terakhir. Hal ini menunjukkan kurangnya semangat kerja dan tanggung jawab terhadap pekerjaan.

Dari sisi penempatan pegawai,khususnya ASN masih banyak yang belum sesuai dengan kualifikasi yang dimilikinya. Berikut disajikan beberapa data penempatan pegawai yang tidak sesuai pada Sekretariat Daerah:

Tabel 4 Data Penempatan Jabatan Pelaksana ASN Sekretariat Daerah Kabupaten Rokan Hulu Sesuai Kualifikasi Pendidikan.

\begin{tabular}{|c|l|l|l|c|}
\hline No. & \multicolumn{1}{|c|}{ Nama Jabatan Pelaksana } & \multicolumn{1}{|c|}{$\begin{array}{c}\text { Kualifikasi Pendidikan Semestinya } \\
\text { (Permenpan Nomor 18 Tahun 2017) }\end{array}$} & $\begin{array}{c}\text { Pendidikan } \\
\text { Pegawai yang } \\
\text { Menjabat }\end{array}$ & Keterangan \\
\hline 1 & Analis Keuangan & $\begin{array}{l}\text { SI/Diploma IV dibidang } \\
\text { Akuntansi/Ekonomi Pembangunan }\end{array}$ & SLTA & Tidak sesuai \\
\hline 2 & Analis Tata Usaha & $\begin{array}{l}\text { SI/Diploma IV dibidang } \\
\text { Manajemen/Ekonomi/Ilmu } \\
\text { Pemerintahan/Ilmu Administrasi/Kebijakan } \\
\text { Publik/Ilmu Hukum }\end{array}$ & - & $\begin{array}{l}\text { Belum ada ASN } \\
\text { yang mengisi } \\
\text { jabatan/ diisi } \\
\text { oleh tenaga } \\
\text { Honorer/PTT }\end{array}$ \\
\hline 3 & Analisis Kebijakan Klasifikasi Barang & $\begin{array}{l}\text { SI/Diploma IV dibidang Manajemen/Ilmu } \\
\text { Pemerintahan/Akuntansi }\end{array}$ & SLTA & Tidak sesuai \\
\hline 4 & $\begin{array}{l}\text { Pengadministrasi Data Peraturan } \\
\text { Perundang-Undangan }\end{array}$ & $\begin{array}{l}\text { Sarjana (S1)/ Diploma IV di bidang Ilmu } \\
\text { Hukum/ Ilmu Administrasi/ Ilmu } \\
\text { Pemerintahan }\end{array}$ & SLTA & Tidak sesuai \\
\hline \hline
\end{tabular}


PENGARUH KEPEMIMPINAN DAN PENEMPATAN TERHADAP SEMANGAT KERJA DAN KINERJA PEGAWAI SEKRETARIAT DAERAH KABUPATEN ROKAN HULU

\begin{tabular}{|c|l|l|c|c|}
\hline No. & \multicolumn{1}{|c|}{ Nama Jabatan Pelaksana } & \multicolumn{1}{|c|}{$\begin{array}{c}\text { Kualifikasi Pendidikan Semestinya } \\
\text { (Permenpan Nomor 18 Tahun 2017) }\end{array}$} & $\begin{array}{c}\text { Pendidikan } \\
\text { Pegawai yang } \\
\text { Menjabat }\end{array}$ & $\begin{array}{c}\text { Keterangan } \\
\text { Tean }\end{array}$ \\
\hline 5 & $\begin{array}{l}\text { Penyusun Rencana Kegiatan dan } \\
\text { Anggaran }\end{array}$ & $\begin{array}{l}\text { Sarjana (S1)/ Diploma IV di bidang } \\
\text { Manajemen/ Ekonomi }\end{array}$ & SLTA \\
\hline 6 & Pengelola Pertanahan & $\begin{array}{l}\text { Minimal Diploma III di bidang Ilmu } \\
\text { Pertanahan/ Administrasi/ Akuntansi/ } \\
\text { Manajemen }\end{array}$ & SLTA \\
\hline 7 & Analis Publikasi & $\begin{array}{l}\text { Sarjana (S1)/ Diploma IV di bidang Ilmu } \\
\text { Ilmu Hukum / Ilmu Komunikasi }\end{array}$ & SLTA \\
\hline 8 & Asisten Pelelang & $\begin{array}{l}\text { Diploma III di bidang Akuntansi/ } \\
\text { Manajemen/ Administrasi }\end{array}$ & SLTA \\
\hline 9 & Analis Kebijakan Lelang & $\begin{array}{l}\text { Sarjana (S1)/ Diploma IV di bidang } \\
\text { Akuntansi/ Manajemen/ Ekonomi } \\
\text { Pembangunan }\end{array}$ & $\begin{array}{l}\text { S2 Ilmu } \\
\text { Pemerintahan }\end{array}$ & Tidak sesuai \\
\hline 10 & $\begin{array}{l}\text { Analis Pemerintahan Umum dan } \\
\text { Otonomi Daerah }\end{array}$ & $\begin{array}{l}\text { Sarjana (S1)/ Diploma IV di bidang Ilmu } \\
\text { Pemerintahan/ Manajemen/ Kebijakan } \\
\text { Publik }\end{array}$ & SLTA \\
\hline
\end{tabular}

Sumber : DUK dan Dokumen ANJAB Sekretariat Daerah Kabupaten Rokan Hulu, Tahun 2018 (Diolah)

Berdasarkan tabel 4 dapat dilihat bahwa masih banyak jabatan pelaksana yang diisi oleh ASN Sekretariat Daerah Kabupaten Rokan Hulu penempatannya tidak sesuai dengan kualifikasi pendidikannya, meskipun dari sisi kepangkatan mungkin tidak menjadi persoalan dalam penempatan pegawai negeri sipil dari sisi aturan kepegawaian, namun hal ini akan menjadi persoalan jika pegawai yang bersangkutan dihadapkan pada permasalahan teknis sesuai dengan tugas pokok dan fungsinya. Beberapa jabatan pelaksana juga belum diisi oleh ASN akan tetapi diisi oleh tenaga honorer/ pegawai tidak tetap.

Pemimpin yang berhasil adalah seorang pemimpin yang mampu membangkitkan semangat kerja dan menanamkan rasa percaya diri serta tanggung jawab pada bawahan untuk melaksanakan tugastugasnya dengan penuh tanggung jawab guna mencapai tujuan organisasi. Semangat kerja karyawan akan muncul diantaranya dari gaya kepemimpinan ideal yang diterapkan seorang pemimpin dalam suatu organisasi untuk mencapai tujuan secara maksimal, sehingga pemimpin mampu menggerakkan orang lain, dalam hal ini adalah pegawai yang menjadi bawahannya.

Dari hasil pengamatan peneliti di lapangan ditemukan beberapa masalah yang dihadapi Aparatur Sipil Negara dalam hal kepemimpinan yang terjadi sebagai berikut:

1. Pimpinan kurang memberikan dorongan Aparatur Sipir Negara dalam menyelesaikan pekerjaan.

2. Pimpinan tidak melakukan pengawasan secara langsung terhadap pekerjaan yang diberikan.

3. Kurangnya ketegasan pimpinan dalam memberikan sanksi kepada Aparatur Sipir Negara yang tidak disiplin.

\section{Perumusan Masalah}

Berdasarkan latar belakang masalah yang dikemukakan sebelumnya dapat dirumuskan rumusan masalah sebagai berikut:
1. Apakah ada pengaruh kepemimpinan terhadap semangat kerja? 
2. Apakah ada pengaruh penempatan terhadap semangat kerja?

3. Apakah ada pengaruh kepemimpinan terhadap kinerja?

4. Apakah ada pengaruh penempatan terhadap kinerja?

5. Apakah ada pengaruh penempatan terhadap terhadap kinerja pegawai melalui semangat kerja?

6. Apakah ada pengaruh kepemimpinan terhadap terhadap kinerja pegawai melalui semangat kerja?

7. Apakah ada pengaruh penempatan dan kepemimpinan secara simultan terhadap kinerja pegawai melalui semangat kerja?

\section{Tujuan Penelitian}

Sesuai dengan latar belakang masalah dan perumusan masalah maka tujuan dari penelitian ini adalah sebagai berikut:

1. Untuk mengetahui pengaruh kepemimpinan

terhadap semangat kerja;

2. Untuk mengetahui pengaruh penempatan terhadap semangat kerja;

3. Untuk mengetahui pengaruh kepemimpinan terhadap kinerja;

4. Untuk mengetahui pengaruh penempatan terhadap kinerja;

5. Untuk mengetahui pengaruh penempatan terhadap terhadap kinerja pegawai melalui semangat kerja;

6. Untuk mengetahui pengaruh kepemimpinan terhadap terhadap kinerja pegawai melalui semangat kerja;

7. Untuk mengetahui pengaruh penempatan dan kepemimpinan secara simultan terhadap kinerja pegawai melalui semangat kerja.

\section{Manfaat Penelitian}

Adapun manfaat penelitian yang diharapkan oleh penulis adalah sebagai berikut:

1. Teoritis

Penelitian ini diharapkan secara teoritis dapat memperkaya ilmu pengetahuan dan sebagai sumbangan pemikiran dalam bidang ilmu yang sesuai.

2. Praktis

a. Sebagai aplikasi dari teori-teori yang diperoleh pada Fakultas Ekonomi Universitas Riau;

b. Sebagai bahan masukan bagi Sekretariat Daerah Kabupaten Rokan Hulu dalam meningkatkan kinerja pegawai;

c. Hasil penelitian dapat digunakan sebagai bahan masukan kepada peneliti lain yang ingin meneliti tentang perngaruh kepemimpinan dan penempatan terhadap semangat kerja dan kinerja pegawai.

\section{TELAAH PUSTAKA \\ Teori Kinerja}

Menurut Gary Dessler (2010) kinerja (prestasi kerja) karyawan adalah prestasi aktual karyawan dibandingkan dengan prestasi yang diharapkan dari karyawan. Prestasi kerja yang diharapkan adalah prestasi standar yang disusun sebagai acuan sehingga dapat melihat kinerja karyawan sesuai dengan posisinya dibandingkan dengan standar yang dibuat. Selain itu dapat juga dilihat kinerja dari karyawan tersebut terhadap karyawan lainnya. 


\section{Indikator Kinerja}

Robbins (2011) mengatakan hampir semua cara pengukuran kinerja mempertimbangkan hal-hal sebagai berikut: 1) Kuantitas; 2) Kualitas; dan 3) Ketepatan Waktu.

\section{Semangat Kerja}

Menurut Hasibuan (2010) menyatakan: "Semangat kerja adalah keinginan dan kesungguhan seseorang mengerjakan pekerjaannya dengan baik serta berdisiplin untuk mencapai prestasi kerja yang maksimal, akan merangsang seseorang untuk berkarya dan beraktifitas dalam pekerjaannya".

Indikator Semangat Kerja yang dikemukakan oleh Nitisemito dalam Nugroho (2015), semangat kerja pegawai berkaitan dengan :1) Tingkat Absensi; 2) Kegelisahan Pegawai; 3) Tuntutan dari pegawai; 4) Pemogokan kerja oleh pegawai.

\section{Kepemimpinan}

Menurut Robbins (2010) kepemimpinan adalah kemampuan untuk mempengaruhi kelompok menuju pencapaian sasaran.

Sedangkan Menurut Edison dkk (2017) kepemimpinan adalah kemampuan untuk mempengaruhi kelompok menuju pencapaian sasaran yang telah ditetapkan. Indikator kepemimpinan adalah : 1) Memiliki strategi yang jelas dan dikomunikasi dengan baik; 2) Kepedulian kepada anggota dan lingkungan; 3) Merangsang anggota; 4) Menjaga kekompakan tim; 4) Menghargai perbedaan.

\section{Penempatan Kerja}

Schuler dan Jackson (2009) mengemukakan

penempatan (placement) berkaitan dengan pencocokan seseorang dengan jabatan yang akan dipegangnya. Sedangkan Mathis dan Jackson (2006) mengemukakan penempatan adalah menempatkan seseorang ke posisi pekerjaan yang tepat.

Schuler dan Jackson (2009;276) mengemukakan tepat tidaknya penempatan seseorang bergantung pada kesesuaian antara pengetahuan, keterampilan dan kemampuan seseorang dan tuntutan job, juga kecocokan antara kepribadian, minat kesukaan serta kesempatan, dan budaya yang terkait dengan perusahaan secara keseluruhan.

Kesesuaian pengetahuan, keterampilan dan kemampuan akan sangat mendukung karyawan dalam pelaksanan tugasnya. "Memiliki pengetahuan, keterampilan dan kemampuan yang dibutuhkan adalah hal yang penting agar karyawan dapat melaksanakan pekerjaan dengan baik" (Mathis dan Jackson, 2006).

\section{Kerangka Pemikiran}

Berdasarkan

rumusan masalah, telaah pustaka dan penelitian terdahulu dapat diambil kerangka berpikir dalam penelitian ini sebagai berikut:

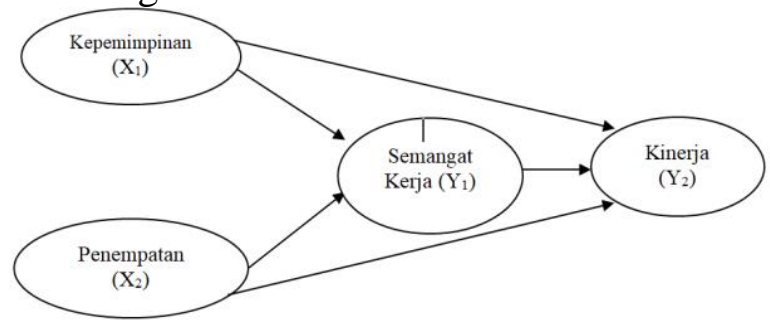

Gambar 1 Model Penelitian 


\section{Hipotesis}

Berdasarkan rumusan masalah, kerangka pemikiran dan penelitian-penelitian terdahulu maka peneliti mengajukan hipotesis sebagai berikut:

1. Kepemimpinan berpengaruh terhadap semangat kerja pegawai;

2. Penempatan kerja berpengaruh terhadap terhadap semangat kerja pegawai;

3. Kepemimpinan berpengaruh berpengaruh terhadap kinerja pegawai;

4. Penempatan berpengaruh terhadap kinerja pegawai.

5. Semangat kerja berpengaruh terhadap kinerja pegawai;

6. Kepemimpinan berpengaruh terhadap kinerja pegawai melalui semangat kerja.

7. Penempatan berpengaruh terhadap kinerja pegawai melalui semangat kerja.

\section{METODE PENELITIAN \\ Desain Penelitian}

Penelitian ini merupakan penelitian deskriptif kuantitatif yaitu memberikan gambaran suatu data analisis secara statistik, sistematis, akurat, dan jelas.

\section{Tempat dan Waktu Penelitian} Penelitian ini akan dilakukan di Kabupaten Rokan Hulu dengan subjek pegawai Sekretariat Daerah Kabupaten Rokan Hulu.

\section{Populasi dan Sampel}

Populasi pada penelitian ini adalah Pegawai Negeri Sipil Sekretariat Daerah Kabupaten Rokan Hulu sebanyak 103 orang. Agar data yang diperoleh representatif maka seluruh populasi dijadikan sampel dalam penelitian atau dengan metode sensus. Untuk variable Kepemimpinan dan Penempatan responden yang di jadikan sampel adalah pegawai ASN level jabatan staf, sedangkan untuk variable semagat kerja dan kinerja responden yang di jadikan sampel adalah level eselon II, III dan IV.

\section{Variabel Penelitian}

Penelitian ini menggunakan 4 variabel yaitu terbagi menjadi 2 variabel bebas (Independent) yaitu, Kepemimpinan $\left(\mathrm{X}_{1}\right)$, Penempatan $\left(\mathrm{X}_{2}\right)$ dan; 1 variabel intervening yaitu semangat kerja $\left(\mathrm{Y}_{1}\right)$ dan 1 variabel terikat (dependent) yaitu kinerja $\left(\mathrm{Y}_{2}\right)$

\section{Teknik Pengumpulan Data}

a. Data Primer

Yaitu dalam bentuk pertanyaan tertutup yang diajukan kepada para ASN Sekretariat Daerah Kabupaten Rokan Hulu yang telah ditetapkan sebagai sampel.

b. Data Sekunder

Dilakukan dengan mengumpulkan beberapa literatur, dokumentasi, laporanlaporan dan tulisan-tulisan ilmiah serta pendukung lainnya yang berkaitan dengan penulisan penelitian ini.

\section{Teknik Analisis Data}

Teknik analisis yang dipakai pada penelitian ini adalah dengan metode Path Analisys untuk mengukur seberapa besar pengaruh 
Kompetensi kepemimpinan dan penempatan terhadap semangat kerja dan kinerja pegawai pegawai Sekretariat Daerah Kabupaten Rokan Hulu dengan bantuan SPSS versi 21. Pengujian lain dalam penelitian ini adalah uji Validitas, Uji Reliabilitas, Uji Korelasi dan Regresi.

\section{HASIL DAN PEMBAHASAN \\ Uji Korelasi}

Pengujian pertama dilakukan dengan menguji hubungan antara variable dependent yaitu Kepemimpinan dan penempatan kerja. Hasil uji korelasi antara variable dependent dapat ditampilkan pada table berikut:

Tabel 5 Hasil Uji Korelasi Variabel Kepemimpinan dan Penempatan.

\begin{tabular}{|c|c|c|c|}
\hline \multicolumn{4}{|c|}{ Correlations } \\
\hline \multicolumn{2}{|c|}{ Variabel } & X1_Kepemimpinan & X2_Penempatan \\
\hline \multirow[t]{3}{*}{ X1_Kepemimpinan } & Pearson Correlation & 1 &, $794^{\star *}$ \\
\hline & Sig. (2-tailed) & & 000 \\
\hline & $\mathrm{N}$ & 47 & 47 \\
\hline \multirow[t]{3}{*}{ X2_Penempatan } & Pearson Correlation & ,794 & 1 \\
\hline & Sig. (2-tailed) &, 000 & \\
\hline & $\mathrm{N}$ & 47 & 47 \\
\hline
\end{tabular}

Sumber Data : Olahan data SPSS (2019)

Dari hasil pengujian didapatkan nilai pearson correlation sebesar 0,794 dan nilai sig. (2tailed) sebesar 0,000. Hal ini berarti terdapat hubungan yang positif dan significan antara variabel kepemimpinan dengan penempatan kerja.

\begin{abstract}
Analisis Jalur (Path Analysis)
Untuk mengetahui pengaruh antar variable independent dan variable dependent maka dilakukan uji regresi untuk mendapatkan nilai pengaruh yang selanjutnya dimasukkan ke persamaan regresi sebagai berikut:
\end{abstract}

\section{Persamaan Regresi I}

Tabel 6 Hasil Uji Pengaruh Kepemimpinan dan Penempatan Terhadap Semangat Kerja Pegawai.

\begin{tabular}{|c|c|c|c|c|c|c|}
\hline \multirow{2}{*}{\multicolumn{2}{|c|}{ Model }} & \multicolumn{2}{|c|}{ Unstandardized Coefficients } & \multirow{2}{*}{$\begin{array}{c}\begin{array}{c}\text { Standardized } \\
\text { Coefficients }\end{array} \\
\text { Beta }\end{array}$} & \multirow[t]{2}{*}{$\mathrm{t}$} & \multirow[t]{2}{*}{ Sig. } \\
\hline & & $\mathrm{B}$ & Std. Error & & & \\
\hline \multirow{3}{*}{1.} & (Constant) & $-1,310$ & 1,775 & &,- 738 & ,464 \\
\hline & X1_Kepemimpinan & ,546 & 128 & ,657 & 4,260 &, 000 \\
\hline & X2_Penempatan &, 165 &, 168 &, 152 & 986 & ,330 \\
\hline \multicolumn{7}{|c|}{$\begin{array}{l}\text { Dependent Variable: Y1_Semangat_Kerja } \\
\text { R Square }=, 613 \\
\text { Adjusted R Square }=, 595 \\
\text { Sig F }=, 000\end{array}$} \\
\hline
\end{tabular}

Sumber Data : Data Olahan SPSS (2019)

Dari table tersebut dapat dibuat persamaan regresi sebagai berikut: $\mathrm{Y}_{1}=0,657 \mathrm{X}_{1}+\mathbf{0 , 1 5 2} \mathrm{X}_{2}+0,387$ Dari table dan persamaan diatas dapat dijelaskan secara simultan kepemimpinan dan penempatan berpengaruh positif dan signifikan terhadap semangat kerja 
pegawai. Besaran pengaruh simultan adalah $\mathrm{R}^{2}$ (R Squre) sebesar 0,613 atau memiliki kontribusi sebesar $61,3 \%$, sedangkan sisanya $38,7 \%$ dipengaruhi faktor lain di luar model. Model simultan ini terjadi secara signifikan. Hal ini dapat dilihat dari probability (sig) atau $<0,01$.

Pengujian signifikansi lebih lanjut diteruskan dengan pengujian individual melalui parameter statistik t. Hasil pengujian individual menunjukkan dengan memperhatikan perolehan sig sebesar $0,000<0,01$ pada jalur $X_{1}$. Sedangkan pada jalur $\mathrm{X}_{2}$ menunjukkan pengaruh yang tidak signifikan dengan sig sebesar
0,330 lebih besar dari standar yaitu 0,01 .

Besaran pengaruh parsial kepemimpinan berpengaruh positif dan significan terhadap semangat kerja adalah sebesar 0,657 atau sebesar $65,7 \%$, sedangkan sisanya $34,3, \%$ dipengaruhi faktor lain di luar model. Sedangkan variable penempatan berpengaruh positif namun tidak signifikan terhadap semangat kerja pegawai sebesar 0,152 atau 15,2\%. Artinya, tinggi rendahnya semangat kerja pegawai dipengaruhi oleh penempatan sebesar $15,2 \%$, sedangkan sisanya $84,8 \%$ dipengaruhi faktor lain di luar model.

\section{Persamaan Regresi II}

Tabel 7 Hasil Uji Pengaruh Kepemimpinan dan Penempatan Terhadap Kinerja Pegawai.

\begin{tabular}{|c|c|c|c|c|c|c|}
\hline \multirow{2}{*}{\multicolumn{2}{|c|}{ Model }} & \multicolumn{2}{|c|}{ Unstandardized Coefficients } & \multirow{2}{*}{$\begin{array}{c}\begin{array}{c}\text { Standardized } \\
\text { Coefficients }\end{array} \\
\text { Beta }\end{array}$} & \multirow[t]{2}{*}{$\mathrm{t}$} & \multirow[t]{2}{*}{ Sig. } \\
\hline & & B & Std. Error & & & \\
\hline \multirow[t]{4}{*}{1} & (Constant) & 2,967 & 1,262 & & 2,351 & ,021 \\
\hline & X1_Kepemimpinan & , 124 & ,048 & ,268 & 2,607 & 011 \\
\hline & X2_Penempatan &, 058 & 070 & 075 & 827 & 410 \\
\hline & Y1_Semangat_Keria & .285 & .072 & 372 & 3,943 & .000 \\
\hline \multicolumn{7}{|c|}{$\begin{array}{l}\text { Dependent Variable: Y2_Kinerja } \\
\text { R Square = ,349 } \\
\text { Adjusted R Square }=, 329 \\
\text { Sig F }=, 000\end{array}$} \\
\hline
\end{tabular}

Sumber Data : Data Olahan SPSS (2019)

Dari table tersebut dapat dibuat persamaan regresi sebagai berikut:

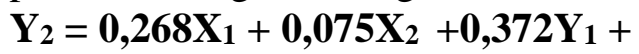
0,409

Dari table dan persamaan diatas dapat dijelaskan secara simultan kepemimpinan, penempatan dan semangat kerja berpengaruh positif dan signifikan terhadap kinerja pegawai. Besaran pengaruh simultan adalah R Square 0,349 atau memiliki kontribusi sebesar 34,9\%, sedangkan sisanya $65,1 \%$ dipengaruhi faktor lain di luar model. Model simultan ini terjadi secara signifikan. Hal ini dapat dilihat dari probability (sig) $<0,01$.

Pengujian signifikansi lebih lanjut diteruskan dengan pengujian individual melalui parameter statistik t. Hasil pengujian individual menunjukkan dengan memperhatikan pada jalur $\mathrm{X}_{1}$ Sig sebesar 0,011 lebih besar dari 0,01 yang berarti tidak signifikan. Pada jaliur $\mathrm{X}_{2}$ Sig sebesar 0,410 lebih besar dari 0,01 yang 
berarti tidak signifikan. Sedangkan pada jalur $\mathrm{Y}_{1}$ menunjukkan pengaruh signifikan dengan sig sebesar 0,000 lebih kecil dari standar yaitu 0,01 .

Besaran pengaruh parsial kepemimpinan berpengaruh positif dan tidak significan terhadap kinerja adalah sebesar 0,268 atau sebesar $26,8 \%$. Secara parsial penempatan berpengaruh positif namun tidak signifikan terhadap kinerja pegawai sebesar 0,075 atau 7,5\%. Artinya, tinggi rendahnya kinerja pegawai dipengaruhi oleh penempatan sebesar $7,5 \%$, sedangkan sisanya $92,5 \%$ dipengaruhi faktor lain di luar model. Sedangkan besaran pengaruh parsial semangat kerja berpengaruh positif dan significan terhadap kinerja adalah sebesar 0,372 atau sebesar $37,2 \%$.

Berdasarkan tabel, dan persamaan regresi secara ringkas dapat dituangkan kedalam table sebagai berikut:

Tabel 8 Hasil Pengujian Hipotesis Pengaruh Langsung

\begin{tabular}{|l|l|l|l|l|l|}
\hline \multicolumn{1}{|c|}{ No } & $\begin{array}{c}\text { Variabel } \\
\text { Independen }\end{array}$ & $\begin{array}{c}\text { Variabel } \\
\text { Dependen }\end{array}$ & $\begin{array}{c}\text { Koefisien } \\
\text { Jalur }\end{array}$ & \multicolumn{1}{c|}{ Sig. } & Keterangan \\
\hline 1. & Kepemimpinan & Kinerja & 0,268 & 0,011 & Signifikan \\
\hline 2. & Penempatan & Kinerja & 0,075 & 0,410 & Signifikan \\
\hline 3. & Semangat Kerja & Kinerja & 0,372 & 0,000 & Signifikan \\
\hline 4. & Kepemimpinan & Semangat Kerja & 0,657 & 0,000 & Signifikan \\
\hline 5. & Penempatan & Semangat Kerja & 0,152 & 0,330 & Signifikan \\
\hline
\end{tabular}

Sumber Data : Data Olahan SPSS (2019)

Sedangkan untuk pengaruh tidak langsung (indirect effect) dapat ditampilkan perhitungan sebagai berikut :

1. Pengaruh tidak langsung (indirect effect) kepemimpinan terhadap kinerja melalui semangat kerja $\left(\begin{array}{llll}\mathrm{X}_{1} \mathrm{ke} & \mathrm{Y}_{2} \text { melalui } \mathrm{Y}_{1}\end{array}\right)=$ $\rho \mathrm{x}_{1} \mathrm{y}_{1} \times \rho \mathrm{y}_{1} \mathrm{y}_{2}=(0,504) \times(0,527)$ $=0,266$. Dengan demikian pengaruh totalnya $=\rho \mathrm{y}_{2} \mathrm{x}_{1}+\mathrm{IE}=$ $0,455+0,266=0,711$.

2. Pengaruh tidak langsung (indirect effect) penempatan terhadap kinerja melalui semangat kerja pegawai $\left(\mathrm{X}_{2} \mathrm{ke}\right.$ $\mathrm{Y}_{2)}$ melalui $\mathrm{Y}_{1}=$ $\rho \mathrm{x}_{2} \mathrm{y}_{1} \quad \mathrm{x} \rho \mathrm{y}_{1} \mathrm{y}_{2}=(0,013) \quad \mathrm{x}$ $(0,527)=0,007$. Dengan demikian pengaruh totalnya $=$ $\rho \mathrm{y}_{2} \mathrm{x}_{2}+\mathrm{IE}=0,080+0,007=$ 0,087

Hasil pengujian pengaruh tidak langsung dapat ditampilkan pada tabel berikut:

Tabel 9 Hasil Pengujian Hipotesis Pengaruh Tidak Langsung

\begin{tabular}{|l|l|l|l|l|}
\hline No & Variabel Independen & Variabel Intervening & Variabel Dependen & Koefisien \\
\hline 1. & Kepemimpinan & Semangat Kerja & Kinerja & 0,711 \\
\hline 2. & Penempatan & Semangat Kerja & Kinerja & 0,087 \\
\hline
\end{tabular}


\begin{tabular}{|l}
$\mid$ \\
Sumber Data : Data Olahan SPSS (2019)
\end{tabular}

Untuk lebih jelasnya hasil analisis jalur (path Analysis) untuk masing-masing variabel yaitu : kepemimpinan, penempatan kerja, semangat kerja, dan kinerja dapat dibuat model sebagai berikut:

PEMBAHASAN HASIL PENELITIAN

\section{Pengaruh \\ Kepemimpinan \\ Terhadap Semangat Kerja Pegawai.}

Hasil pengujian menunjukkan bahwa koefisien direct effect kepemimpinan terhadap semangat kerja karyawan adalah sebesar 0,504 dan signifikan (sig.) $(<0,01)$. Hal ini menunjukkan bahwa $\left(\mathrm{H}_{1}\right)$ diterima yaitu ada pengaruh yang signifikan antara kepemimpinan terhadap semangat kerja pegawai. Besaran pengaruh $0,504 \quad(50,4 \%)$ dapat diartikan bahwa semangat kerja pegawai di Sekretariat Daerah dipengaruhi oleh variable kepemimpinan sebesar $50,4 \%$ Semakin baik kepemimpinan yang ditunjukkan dan dipraktekkan maka semakin mendorong semangat kerja pegawai Sekretariat Daerah. Sedangkan sisanya $49,6 \%$ dipengaruhi oleh variable lain diluar model penelitian ini.

$$
\text { Hasil penelitian ini }
$$
mendukung penelitian yang dilakukan oleh Ni Wayan Anggreni (2018) hasil penelitiannya menyimpulkan kepemimpinan memiliki pengaruh positif dan tidak signifikan terhadap kinerja karyawan Pantai Prama Sanur Hotel. Kepemimpinan memiliki positif dan

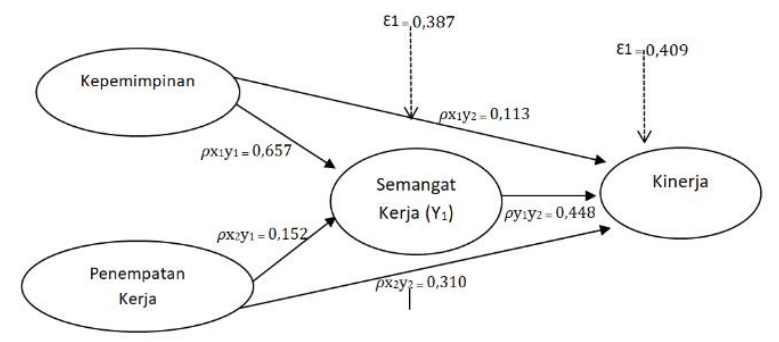

pengaruh signifikan terhadap semangat kerja karyawan. Hasil ini menyiratkan bahwa kepemimpinan yang baik sangat mendukung semangat kerja karyawan.

Pemimpin yang berhasil adalah pemimpin yang bisa memberikan motivasi kepada pegawainya sehingga muncul semangat kerja dan tanggungjawab dalam menyelesaikan pekerjaan. Pegawai yang memiliki semangat kerja akan cenderung berkarya dan berkreatifitas dalam pekerjaannya. Beberapa cara yang dapat dilakukan untuk memberikan semangat kerja antara lain dengan memberikan penghargaan dan motivasi berupa promosi jabatan yang lebih tinggi sesuai dengan masa kerja dan hasil pekerjaan karyawan, selalu berkomunikasi dengan bawahan, menjaga kekompakan tim dan selalu memperhatikan lingkungan tempat kerja.

Kepemimpinan memberikan pengaruh terhadap semangat kerja pegawai yang dihasilkan oleh aparatur dalam organisasi. Sebab dengan adanya kepemimpinan yang baik dan diinginkan oleh aparatur, tentunya akan tercipta komunikasi dan interaksi yang antara pimpinan dengan bawahan. Kepemimpinan yang dijalankan harus sesuai dan 
didukung oleh bawahannya, sehingga program kerja dan kebijakan yang ditetapkan oleh pimpinan dapat dilaksanakan dengan benar. Selain itu juga faktor kepemimpinan yang ditinjau dari karakteristik, gaya dan motivasi yang dimiliki oleh pimpinan, akan sangat membantu dalam membangkitkan semangat kerja pegawai pada Sekretariat Daerah Kabupaten Rokan Hulu. Oleh karena itu memiliki pemimpin yang komunikatif, berkemampuan, yang didukung oleh bawahan dan mampu memberikan motivasi, tentunya akan sangat membantu semangat kerja pegawai dalam meningkatkan kinerjanya.

Kemudian kepemimpinan juga membutuhkan dukungan dari setiap elemen dan unit kerja yang ada dalam organisasi. Karena bentuk dukungan yang diberikan akan menjadi spirit bagi setiap komponen dan unit organisasi untuk bisa saling bekerjasama dalam merealiasikan tujuan yang telah ditetapkan. Seorang pemimpin juga harus berjiwa mengayomi kepada setiap bawahan yang dimilikinya, sehingga bawahan akan sangat diperhatikan oleh pimpinan dalam melaksanakan tugasnya. Bentuk perhatian yang dilakukan akan memberikan semangat kerja pegawai dalam setiap pelaksanaan tugas yang dibebankan.

\section{Pengaruh Penempatan Kerja Terhadap Semangat Kerja Pegawai.}

Hasil pengujian menunjukkan bahwa koefisien direct effect penempatan terhadap semangat kerja pegawai adalah sebesar 0,013 dan signifikan (sig. ) >0,01). Hal ini menunjukkan bahwa $\left(\mathrm{H}_{2}\right)$ diterima yaitu ada pengaruh antara penempatan terhadap semangat kerja pegawai akan tetapi tidak signifikan. Besaran pengaruh $0,013 \quad(1,3 \%)$ menunjukkan bahwa penempatan kerja berpengaruh terhadap semangat kerja namun cukup kecil dan tidak significan. Semakin sesuai latar belakang pendidikan, pengetahuan kerja dan pengalaman kerja pegawai dengan jabatan yang diembannya maka akan mendorong semangat kerja pegawai tersebut.

Hasil penelitian ini sesuai dengan teori yang dikemukakan oleh Mathis dan Jackson (2006), "Memiliki pengetahuan, keterampilan dan kemampuan yang dibutuhkan adalah hal yang penting agar karyawan dapat melaksanakan pekerjaan dengan baik".

Penempatan kerja pegawai yang sesuai dengan latar belakang pendidikan, pengetahuan, keterampilan, dan pengalaman kerjanya akan cenderung memberikan motivasi sehingga pegawai yang bersangkutan bersemangat dalam melaksanakan aktifitas dan pekerjaannya seharihari. Keterampilan dalam melaksanakan tugas juga menunjukkan kemampuan dari pegawai karena keterampilan yang dimiliki pegawai untuk melaksanakan tugas-tugasnya menunjukkan kemampuan pegawai itu sendiri dan sesuai dengan penempatan pegawai. Keterampilan juga sangat erat kaitannya dengan SDM. Gie (2003) mengatakan bahwa kegiatan menguasai sesuatu keterampilan dengan tambahan bahwa mempelajari keterampilan harus dibarengi dengan kegiatan praktis, berlatih dan mengulangulang suatu kerja. Seseorang yang memahami semua asas, metode, pengetahuan dan teori dan mampu 
melaksanakan secara praktis adalah orang yang memiliki keterampilan.

Penempatan juga butuh pengalaman dan tentunya pengalaman harus bisa dijadikan pegangan didalam mengambil suatu keputusan. Sebagaimana teori yang dikemukakan Hasibuan (2000) bahwa pengalaman seseorang merupakan salah satu spesifikasi yang dibutuhkan dalam melaksanakan suatu pekerjaan. Konsep ini sangat relevan dengan tugas-tugas penyelenggaraan pelayanan yang ada di Sekretariat Daerah Kabupaten Rokan Hulu yang dalam penempatan pegawainya dibutuhkan pengalaman pegawai dalam upaya meningkatkan semangat kerja pegawai.

Pengaruh Kepemimpinan

\section{Terhadap Kinerja Pegawai.}

Hasil pengujian menunjukkan bahwa koefisien direct effect kepemimpinan terhadap kinerja pegawai sebesar 0,455 dan signifikan (sig.) $(<0,01)$. Hal ini menunjukkan bahwa $\left(\mathrm{H}_{3}\right)$ diterima yaitu ada pengaruh yang signifikan antara kepemimpinan terhadap kinerja pegawai. Besaran pengaruh 0,455 $(45,5 \%)$ artinya pengaruh kepemimpinan terhadap kinerja pegawai sebesar $45,5 \%$ sedangkan pengaruh lainnya sebesar $54,5 \%$ dipengaruhi oleh variable lainnya diluar model penelitian ini. Pemimpin harus mampu merumuskan sasaran dan strategi dalam melaksanakan pekerjaan, memberikan motivasi, dan peduli kepada bawahan sehinnga memberikan peluang yang lebih besar bagi peningkatan kinerja pegawainya.

Hasil
mendukung $\begin{array}{r}\text { penelitian } \\ \text { penitian } \\ \text { yang }\end{array}$

dilakukan oleh Veronica Celattia Tandoh (2011), dengan simpulan hasil penelitian kepemimpinan berpengaruh secara positif dan significan terhadap kinerja dan produktifitas.

Keberhasilan pemimpin dipengaruhi oleh kemampuannya dalam menyusun strategi dalam pelaksanaan pekerjaan, pemberian motivasi pada bawahan, kepedulian pada bawahan dan menjaga kekompakan tim sehingga kinerja pegawai dapat ditingkatkan. Pemimpin diharapakan mampu menciptakan hubungan yang kondusif antar bawahan serta sepandai mungkin mengatur sistem kerja perusahaan yang lebih baik.

Pimpinan Sekretariat Daerah harus melakukan pembinaan pegawai untuk meningkatkan keahlian pegawainya. Memberikan motivasi kepada pegawai untuk meningkatkan pengetahuan dan kemampuannya merupakan salah satu cara agar pegawai dapat memahami arti penting keahlian dan penguasaan di bidang teknologi informasi. Diharapkan setiap pegawai memiliki keahlian, minimal dalam pengoperasian komputer.

Cara lain yang dilakukan oleh pimpinan dalam upaya meningkatkan kinerja pegawainya adalah dengan mengirim pegawai mengikuti pendidikan dan pelatihan baik formal maupun informal. Dalam hal ini pimpinan harus lebih meningkatkan bimbingan kepada pegawai sehingga dengan adanya bimbingan dari pimpinan maka pelaksanaan tugas dari bawahan akan dapat tercapai. Dukungan pimpinan baik melalui sikap dan perilaku, sumbangan pikiran dan dukungan finansial sangat dibutukan oleh bawahan 
dalam melaksanakan tugas. Dalam hal ini dukungan sangat dibutuhkan oleh pegawai sehingga pegawai tidak mengalami keragu-raguan didalam mengambil suatu keputusan. Sebagaimana yang dikemukakan Stewart (1998) bahwa dampak nyata pemberdayaan baru muncul bila para pimpinan melihat bahwa peran utama mereka adalah memberikan dukungan yang tepat, jauh lebih utama daripada peran kepemimpinan tradisional ataupun pentingnya pengendalian. Dalam kontek ini pimpinan tidak lagi berada dipuncak atas yang didukung oleh stafnya melainkan justru dalam piramida terbalik yaitu mendukung staf dengan cara bersikap dan berperilaku serta memberikan sumbangan pikiran.

\section{Pengaruh Penempatan Terhadap} Kinerja Pegawai.

Hasil pengujian menunjukkan bahwa koefisien direct effect penempatan terhadap kinerja sebesar 0,080 dan signifikan (sig.) $(>0,01)$. Hal ini menunjukkan bahwa $\left(\mathrm{H}_{4}\right)$ diterima yaitu ada pengaruh antara penempatan terhadap kinerja pegawai akan tetapi tidak signifikan. Besaran pengaruh penempatan terhadap kinerja sebesar $0,080(8 \%)$ artinya penempatan pegawai memiliki kontribusi pengaruh sebesar 8\% terhadap kinerja pegawai. Pengaruh ini termasuk cukup kecil namun juga harus diperhatikan dalam rangka peningkatan kinerja pegawai. Semakin sesuai latar belakang pendidikan pegawai, pengetahuan kerja dan pengalaman kerja pegawai dengan jabatan yang diembannya maka kinerja pegawai tersebut akan semakin meningkat.

Hasil penelitian ini

mendukung penelitian yang dilakukan oleh Winda Jennifer Rori (2014), asil penelitian menunjukkan bahwa pendidikan, pelatihan dan penempatan kerja baik secara simultan maupun parsial mempunyai pengaruh terhadap kinerja pegawai.

Penempatan

pegawai

semestinya disesuaikan dengan latar belakang pendidikan, pengetahuan, keterampilan, dan pengalaman kerja pegawai sehingga dapat meningkatkan kinerja pegawai.

Menurut Foster (2001) ada beberapa hal yang menentukan keahlian seorang karyawan, yaitu: lama waktu / masa kerja; tingkat pengetahuan dan keterampilan yang dimiliki serta penguasaan terhadap pekerjaan dan peralatan. Masa kerja merupakan salah satu hal yang dapat mempengaruhi keahlian seorang pegawai. Hal ini disebabkan pegawai yang memiliki masa kerja yang lama, maka memiliki pengetahuan dan wawasan terhadap pekerjaan yang ditekuni dan memiliki kemampuan untuk mengatasi kesulitan-kesulitan dalam pekerjaan tersebut. Oleh sebab itu, pemilihan pejabat di Sekretariat Daerah Kabupaten Rokan Hulu, salah satunya adalah masa kerja. Hal lain yang menjadi keahlian adalah faktor tingkat pengetahuan dan keterampilan yang dimiliki. Keterampilan merupakan hal yang sangat penting. Pegawai yang terampil dan memiliki pengetahuan akan memiliki keahlian yang lebih baik dibandingkan pegawai yang tidak memiliki pengetahuan. Faktor ketiga adalah penguasaan terhadap pekerjaan dan peralatan. Peralatan yang dapat menunjang pekerjaan, harus dikuasai oleh pegawai. Hal ini untuk menunjang pekerjaan pegawai itu sendiri. Jika mengandalkan 
kemampuan orang lain, maka pegawai tersebut tidak dapat melaksanakan pekerjaan secara cepat. Hal ini akan mempengaruhi kinerja pegawai itu sendiri dalam hal penyelesaian pekerjaan secara cepat dan tepat.

Oleh sebab itu, keahlian menjadi salah satu hal yang dapat meningkatkan kinerja seorang pegawai, termasuk pegawai Sekretariat Daerah Kabupaten Rokan Hulu.

\section{Pengaruh Semangat kerja} Terhadap Kinerja Pegawai.

Hasil pengujian menunjukkan bahwa koefisien direct effect semangat kerja terhadap semangat kinerja pegawai adalah sebesar 0,527 dan signifikan (sig.) $(<0,01)$. Hal ini menunjukkan bahwa $\left(\mathrm{H}_{5}\right)$ diterima yaitu ada pengaruh signifikan antara semangat kerja pegawai terhadap kinerja pegawai. Besaran pengaruh $0,527 \quad(52,7 \%)$ artinya bahwa kontribusi semangat kerja terhadap peninkatan kinerja pegawai sebesar $52,7 \%$ sedangkan $\quad 47,3 \%$ lainnya dipengaruhi oleh variable lainnya diluar model penelitian ini. Pegawai yang bersemangat dalam melaksanakan pekerjaan dan aktivitas kesehariannya di kantor akan memiliki tanggung jawab dalam menyelesaikan pekerjaan sehingga kinerjanya juga akan meningkat.

Hasil penelitian ini mendukung penelitian yang dilakukan oleh Billy Yanis Saputra, Susi Hendriani, Machasin, (2017) dengan judul Pengaruh Kompetensi Dan Penempatan Terhadap Semangat Kerja Dan Kinerja Pegawai Dinas Pendapatan Daerah Kabupaten Bengkalis dengan salah satu temuan hasil penelitian bahwa terdapat pengaruh langsung yang signifikan antara Semangat Kerja terhadap Kinerja pada Pegawai Dinas Pendapatan Daerah Kabupaten Bengkalis.

Secara keseluruhan tanggapan responden terhadap dimensi semangat kerja dikategorikan cukup baik. Dari temuan penulis dilapangan ditemukan jawaban bahwa semangat kerja pegawai memang cukup tinggi namun karena mereka terlalu lama bekerja disatu bidang pekerjaan saja dan jarang dilakukan rotasi pekerjaan maka pegawai kadangkala mulai bosan dan jenuh sehingga motivasi mereka untuk bekerja pun akan menurun. Hal ini sesuai dengan pendapat Siagian, (2003) yang mengatakan bahwa motivasi yang tepat para karyawan akan terdorong untuk berbuat semaksimal mungkin dalam melaksanakan tugasnya, karena mereka meyakini bahwa dengan keberhasilan organisasi mencapai tujuan dan sasarannya maka kepentingan-kepentingan pribadi para pegawai akan tercapai juga, dengan kata lain pegawai termotivasi melakukan tugas pekerjaannya karena mengetahui bahwa pekerjaan yang dilakukan berkaitan dengan sesuatu yang sangat penting baginya. Mereka mengetahui bahwa pekerjaan yang dilakukan membantu dalam mencapai tujuan organisasi.

Pengaruh

Terhadap Kinerja Pegawai Melalui Semangat Kerja.

Hasil pengujian menunjukkan bahwa koefisien pengaruh tidak langsung (indirect effect) kepemimpinan terhadap kinerja melalui semangat kerja $\left(\mathrm{X}_{1}\right.$ ke $\mathrm{Y}_{2}$ melalui $\left.\mathrm{Y}_{1}\right)=\rho \mathrm{x}_{1} \mathrm{y}_{1} \quad \mathrm{x} \rho \mathrm{y}_{1} \mathrm{y}_{2}=$ $(0,504) \times(0,527)=0,266$. Dengan 
demikian pengaruh totalnya $=$ $\rho \mathrm{y}_{2} \mathrm{X}_{1}+\mathrm{IE}=0,455+0,266=0,711$. Hal ini menunjukkan bahwa $\left(\mathrm{H}_{6}\right)$ diterima yaitu ada pengaruh antara kepemimpinan terhadap kinerja melalui semangat kerja pegawai. Dari hasil penelitian menunjukkan bahwa dnegan melibatkan semangat kerja sebagai variable intervening, memberikan pengaruh yang lebih besar dari pengaruh langsung antara kepemimpinan terhadap kinerja pegawai Sekretariat Daerah. Pengaruh total sebesar 0,711 berarti bahwa kepemimpinan melalui semangat kerja memiliki kontribusi sebesar $71,7 \%$ dalam meningkatkan kinerja pegawai Sekretariat Daerah. Sedangkan 38,3\% lainnya dipengaruhi oleh variable lainnya diluar model.

Hasil penelitian ini mendukung penelitian yang dilakukan oleh Veronica Celattia Tandoh (2011), dengan simpulan hasil penelitian kepemimpinan berpengaruh secara positif dan significan terhadap kinerja dan produktifitas.

Keberhasilan pemimpin dipengaruhi oleh kemampuannya dalam menyusun strategi dalam pelaksanaan pekerjaan, pemberian motivasi pada bawahan, kepedulian pada bawahan dan menjaga kekompakan tim sehingga kinerja pegawai dapat ditingkatkan.

\section{Penempatan berpengaruh terhadap kinerja pegawai melalui semangat kerja.}

Hasil pengujian menunjukkan bahwa koefisien Pengaruh tidak langsung (indirect effect) penempatan terhadap kinerja melalui semangat kerja pegawai $\left(\mathrm{X}_{2}\right.$ ke $\left.\mathrm{Y}_{2}\right)$ melalui $\mathrm{Y}_{1}=\rho \mathrm{x}_{2} \mathrm{y}_{1} \times \rho \mathrm{y}_{1} \mathrm{y}_{2}=(0,013)$ $\mathrm{x}(0,527)=0,007$. Dengan demikian pengaruh totalnya $=\rho \mathrm{y}_{2} \mathrm{x}_{2}+\mathrm{IE}=$ $0,080+0,007=0,087$. Hal ini menunjukkan bahwa $\left(\mathrm{H}_{7}\right)$ diterima yaitu ada pengaruh antara penempatan terhadap kinerja pegawai melalui semangat kerja pegawai. Pengaruh total sebesar 0,087 berarti bahwa penempatan melalui semangat kerja memiliki kontribusi sebesar $8,7 \%$ dalam meningkatkan kinerja pegawai Sekretariat Daerah. Dengan melibatkan semangat kerja sebagai variable intervening, memberikan pengaruh yang lebih besar dari pengaruh langsung antara penempatan pegawai terhadap kinerja pegawai. Sehingga perlu diperhatikan factor kesesuaian penempatan pegawai untuk meningkatkan semangat kerja dan pada akhirnya meningkatkan kinerja pegawai Sekretariat Daerah.

Hasil penelitian ini mendukung penelitian yang dilakukan oleh Winda Jennifer Rori (2014), hasil penelitian menunjukkan bahwa pendidikan, pelatihan dan penempatan kerja baik secara simultan maupun parsial mempunyai pengaruh terhadap kinerja pegawai.

Pegawai yang ditempatkan pada jabatan yang sesuai dengan latar belakang pendidikan, pengetahuan, keterampilan, dan pengalaman kerjanya akan cenderung memiliki semangat dalam melaksanakan pekerjaannya. Selain pekerjaan tersebut sesuai dengan latar belakang keilmuannya, pegawai tersebut akan lebih mudah dalam melaksanakan pekerjaan karena dia akan memahami setiap seluk beluk pekerjaan yang ditanganinya sehingga kinerjanya juga akan maksimal.

Dalam hal ini pegawai perlu 
lebih teliti dan tekun didalam melaksanakan tugas pekerjaaannya, sehingga nantinya kita tidak menemukan adanya kesalahan dalam pelaksanaan pekerjaannya. Selain itu untuk menumbuhkan kegairahan dan inisiatif dalam bekerja, pimpinan perlu melakukan suatu pendekatan lain melalui motivasi eksternal, misalnya dalam bentuk pemberian penghargaan, bonus dan promosi jabatan, pegawai berprestasi atau pemberian insentif, sehingga pegawai termotivasi dan berinisiatif untuk berbuat yang terbaik yang pada gilirannya akan meningkatkan kualitas pelayanan kepada masyarakat.

\section{KESIMPULAN DAN SARAN Kesimpulan}

Berdasarkan hasil penelitian dan pembahasan pada bab sebelumnya, maka kesimpulan yang penulis dapatkan yaitu:

1. Kepemimpinan memiliki pengaruh langsung yang positif dan signifikan terhadap semangat kerja pegawai Sekretariat Daerah Kabupaten Rokan Hulu. Pengaruh positif menjelaskan semakin baik kepemimpinan, semakin tinggi semangat kerja pegawai Sekretariat Daerah.

2. Penempatan kerja memiliki pengaruh langsung yang positif tetapi tidak signifikan terhadap semangat kerja pegawai Sekretariat Daerah Kabupaten Rokan Hulu. Pengaruh positif menjelaskan semakin sesuai penempatan pegawai, semakin tinggi semangat kerja pegawai yang bersangkutan.

3. Kepemimpinan memiliki pengaruh langsung yang positif dan signifikan terhadap kinerja pegawai Sekretariat Daerah Kabupaten Rokan Hulu. Pengaruh positif menjelaskan semakin baik kepemimpinan, semakin baik kinerja pegawai Sekretariat Daerah.

4. Penempatan kerja memiliki pengaruh langsung positif tetapi tidak signifikan terhadap kinerja pegawai Sekretariat Daerah Kabupaten Rokan Hulu. Pengaruh positif menjelaskan semakin sesuai penempatan kerja pegawai, semakin tinggi kinerja pegawai Sekretariat Daerah.

5. Semangat kerja memiliki pengaruh langsung positif dan signifikan terhadap kinerja pegawai Sekretariat Daerah Kabupaten Rokan Hulu. Pengaruh positif menjelaskan semakin tinggi semangat kerja pegawai, semakin baik kinerja pegawai Sekretariat Daerah.

6. Kepemimpinan memiliki pengaruh positif tetapi tidak signifikan terhadap kinerja melalui semangat kerja pegawai Sekretariat Daerah Kabupaten Rokan Hulu. Pengaruh positif menjelaskan semakin baik kepemimpinan semakin tinggi semangat kerja dan imbasnya semakin baik pula kinerja pegawai Sekretariat Daerah.

7. Penempatan kerja memiliki pengaruh positif tetapi tidak signifikan terhadap kinerja melalui semangat kerja pegawai Sekretariat Daerah Kabupaten Rokan Hulu. Pengaruh positif menjelaskan semakin sesuai penempatan kerjasemakin tinggi pula semangat kerja pegawai yang selanjutnya meningkatkan 


\section{kinerja pegawai Sekretariat Daerah.}

\section{Saran}

Berdasarkan hasil penelitian, pembahasan hasil penelitian yang telah diuraikan sebelumnya, serta bertitik tolak dari kesimpulan yang telah dikemukakan maka adapun saran-saran sebagai bahan pertimbangan yaitu:

1. Pimpinan di Sekretariat Daerah dalam hal ini level Eselon II, III dan IV perlu membangun komunikasi yang baik dan koordinasi antar bagian dalam lingkup Sekretariat Daerah. Langkah kongkrit yang bisa dilakukan yaitu dengan melaksanakan rapat koordinasi antar bagian minimal sekali dalam sebulan untuk membahas persoalan-persoalan dan hambatan dalam pelaksanaan pekerjaan agar dapat dicari solusi dan pemecahan masalah secara bersama.

2. Pimpinan pada setiap level di Sekretariat Daerah harus mampu merumuskan strategi dalam melaksanakan pekerjaan dan dikomunikasikan dengan bawahan. Sehingga pekerjaan selesai tepat waktu dan kualitasnya sesuai dengan yang diharapkan. Hal ini bisa dilakukan dengan menyusun target sasaran dan strategi yang dituangkan ke dalam rencana kinerja masing- masing sub bagian dan bagian dan di presentasikan dalam suatu forum yang dihadiri oleh pimpinan level eselon II di Sekretariat Daerah.

3. Pekerjaan rutinitas yang dilaksanakan di Sekretariat
Daerah perlu dilakukan monitoring dan evaluasi dari waktu ke waktu sehingga dapat dijadikan acuan dalam penetapan strategi yang lebih tepat dalam percepatan pelaksanaan pekerjaan.

4. Perlu dilakukan pengawasan terhadap bawahan sebagai salah satu bentuk kepedulian atasan terhadap pelaksanaan pekerjaan oleh bawahan. Pimpinan pada level eselon II yaitu Sekretaris Daerah, para Asisten, dan Staf ahli perlu melihat langsung ke setiap Bagian untuk mengontrol pelaksanaan pekerjaan, minimal menanyakan progres pelaksanaan pekerjaan pada Bagian yang dibawahi setiap sebulan sekali.

5. Menempatkan ASN sesuai dengan latar belakang pendidikan, pengetahuan dan keterampilannya. Pegawai yang ditempatkan minimal sesuai dengan strata pendidikan walaupun belum sesuai dengan kualifikasi pendidikan, setidaknya akan memberi motivasi pada pegawai untuk melanjutkan pendidikan ke jenjang yang lebih tinggi.

6. Memberikan kesempatan pada ASN Sekretariat Daerah untuk melanjutkan pendidikan baik itu melalui izin belajar maupun tugas belajar.

7. Menyediakan anggaran yang cukup untuk peningkatan kompetensi pegawai dan mengirim pegawai untuk mengikuti bimtek, kursus, dan diklat untuk meningkatkan pengetahuan dan keterampilannya. 


\section{DAFTAR PUSTAKA}

Edison, Emron dkk. 2017. Manajemen Sumber Daya Manusia. Bandung: Alfabeta.

Foster, Bill. 2001. Pembinaan untuk Peningkatan Kinerja

Karyawan.PPM : Jakarta.

Gary Dessler. 2010 Manajemen Sumber Daya Manusia, Jakarta: PT Indeks, 2010

Ghozali, Imam. 2011. Aplikasi Analisis Multivariate Dengan Program SPSS. Semarang : Badan Penerbit Universitas Diponegoro.

Jackson, Schuler, Werner, 2010, Pengelolaan Sumber Daya Manusia, Edisi 10,. Salemba Empat, Jakarta.

Mathis, Robert L. and John H. Jackson, 2010, Manajemen Sumber Daya Manusia, Jakarta, Edisi Kesepuluh, Salemba Empat.

Robbins, Stephen P. 2010. Organizational Behaviour, Tenth Edition (Perilaku Organisasi. Edisi ke Sepuluh), Alih Bahasa Drs. Benyamin Molan. Jakarta : Salemba Empat.

Siagian, S.P, 2003, Manajemen Sumber Daya Manusia, Jakarta , Bina Aksara.

Stewart Thomas. A, 1998, Modal Intelektual : Kekayaan Baru Organisasi. Jakarta : PT. Elexmedia Komputindo
Sugiyono, 2010, Statistika Untuk Penelitian, Bandung, Cetakan Ke Enambelas, Penerbit CV. Alpha Beta.

-----------,2010, Metode Penelitian Kuantitatif dan Kualitatif dan $R \& D$, Bandung, , Penerbit CV. Alpha Beta.

Wibowo. 2012. Manajemen Kinerja. Jakarta: PT Raja Grafindo Persada.

\section{Jurnal}

Billy Yanis Saputra, Susi Hendriani, Machasin, 2017, Pengaruh Kompetensi Dan Penempatan Terhadap Semangat Kerja Dan Kinerja Pegawai Dinas Pendapatan Daerah Kabupaten Bengkalis, Jurnal Tepak Manajemen Bisnis Vol. IX. No. 2 Mei 2017

Winda Jennifer Rori, Peggy A. Mekel, Imelda Ogi, 2014. Pendidikan, Pelatihan Dan Penempatan Kerja Pengaruhnya Terhadap Kinerja Pegawai Di Kantor Inspektorat Kota Manado. Jurnal EMBA Vol.2 No.2 Juni 2014, Hal. 1284-1295 